\title{
KONEKSI JARINGAN ANTARA DUA KOMPUTER MENGGUNAKAN KABEL USB NETWORK/BRIDGE DENGAN CHIP BRIDGE PL 2501.
}

\author{
Oleh : Nenny Anggraini \\ Email : Nenny_a@yahoo.com \\ Dosen STMIK Jakarta STI\&K
}

\begin{abstract}
Abstraksi
Koneksi jaringan ini berisi tentang membangun jaringan sederhana antara dua buah komputer tanpa menggunakan ethernet card melalui port USB. Permasalahan yang muncul adalah sistem USB didesain hanya untuk berkomunikasi dengan peralatan USB, sehingga antara USB Host Controller pada sebuah komputer tidak dapat secara langsung terkoneksi dengan USB Host Controller pada komputer lainnya.

Dengan menggunakan kabel USB Network/Bridge sebagai peralatan USB, maka USB Host Controller dapat saling berkomunikasi. Kabel USB Network/Bridge ini memiliki rangkaian elektronik yang berfungsi sebagai pengatur lalu lintas data dari USB Host Controller pada komputer A ke USB Host Controller pada komputer B maupun sebaliknya. Sehingga dalam membangun jaringan melalui port USB diperlukan peralatan USB sebagai media komunikasi antara Host Controller.
\end{abstract}

\section{Kata kunci : Jaringan, Kabel USB Network/Bridge, USB Host Controller}

Daftar Pustaka : 6 ( 1996 - 2007 )

\section{PENDAHULUAN}

\subsection{LATAR BELAKANG MASALAH}

Pada awalnya penggunaan teknologi untuk pengolahan data menjadi informasi dilakukan oleh komputer. Namun hal ini dirasakan tidak efisien karena setiap komputer yang digunakan untuk mengolah data harus memuat program aplikasi yang diperlukan, 
dan proses pengolahan datanya pun harus berpindah-pindah dari satu komputer ke komputer lainnya.

Dalam perkembangan media transmisi terutama kabel twisted pair, pada saat ini terdapat suatu jenis pengantarmuka yaitu port Universal Serial Bus (USB) yang sering digunakan untuk transmisi data dari suatu host controller ke peripheral yang memerlukan kabel khusus yaitu kabel USB yang termasuk kedalam jenis kabel twisted pair.

Penggunaan pengantarmuka port USB untuk menghubungkan satu komputer dengan komputer lainnya dapat dilakukan, namun sistem USB pada komputer tidak dapat secara langsung terhubung dengan sistem USB pada komputer lainnya. Karena host controller sistem USB pada komputer didesain hanya untuk berkomunikasi dengan peralatan USB. Sehingga diperlukan sebuah peralatan USB sebagai media komunikasi antar host controller USB pada komputer.

Untuk dapat menghubungkan satu komputer dengan komputer lainnya melalui port USB adalah dengan menggunakan kabel USB Network/Bridge yang memiliki chip bridge yang berfungsi sebagai peralatan USB untuk mengatur transmisi data antar USB host controller pada komputer melalui port USB.

Oleh sebab itu penulis melakukan penelitian mengenai transmisi data antara dua komputer menggunakan kabel USB Network/Bridge dan penulis memberikan judul "Koneksi Jaringan Antara Dua Komputer Menggunakan Kabel USB Network/Bridge dengan Chip Bridge PL 2501'”.

\subsection{TUJUAN}

Tujuan penulis melakukan penulisan ilmiah tentang koneksi jaringan antara dua buah komputer tanpa ethernet card melalui port USB menggunakan kabel USB Network/Bridge dengan chip bridge PL 2501 ini antara lain :

a. Memberikan alternatif baru dalam koneksi jaringan Local Area Network. (LAN) yaitu melalui port USB. Karena banyaknya peralatan yang menggunakan port USB dalam transfer data serta kecepatan transmisi data yang cukup tinggi dibandingkan dengan jaringan yang menggunakan Ethernet 
Card, sehingga akan memudahkan dan meningkatkan kinerja untuk bertukar informasi dalam satu jaringan.

b. Memahami sistematika dan karakteristik dari port USB serta cara kerja kabel USB Network/Bridge dalam transfer data pada koneksi jaringan tanpa ethernet card antara dua komputer.

\subsection{MASALAH}

Masalah yang penulis ingin kemukakan pada penulisan ilmiah ini adalah mengenai sistem USB, port USB, cara pentransmisian data melalui port USB, dan fungsi USB host controller dalam koneksi jaringan antara dua komputer tanpa ethernet card menggunakan kabel USB Network/Bridge.

Pembatasan masalah dalam penulisan ini mengenai fungsi chip bridge PL 2501 pada kabel USB Network/Bridge, serta cara pentransmisian data antar komputer melalui port USB.

\subsection{MANFAAT}

Adapun manfaat dari penelitian ini dengan menggunakan sistem USB adalah mengetahui bagaimana 2 (dua) buah port USB saling terhubung sehingga dapat saling berkomunikasi seperti transfer data,sehingga akan memudahkan serta meningkatkan kinerja untuk bertukar informasi dalam satu jaringan

\section{TINJAUAN PUSTAKA}

\subsection{SISTEM USB (UNIVERSAL SERIAL BUS)}

USB adalah sebuah standar serial bus yang digunakan untuk menghubungkan peralatan. Pada awalnya sistem USB didesain untuk komputer, karena kemudahan dan sifatnya yang umum, penggunaan USB ini diaplikasikan kepada peralatan lain seperti konsol video game, telepon seluler, dan lain-lain. ${ }^{[1]}$ 


\subsection{STANDARISASI USB}

USB memiliki standarisasi yang ditentukan oleh USB-Implementers Forum (USB-IF), sebuah badan yang menstandarisasi produk USB. Terdapat beberapa versi dari USB, antara lain versi 0.9, 1.0, 1.1. Pada april 2000, USB versi 2.0 diluncurkan dan distandarisasi oleh USB-IF pada akhir 2001. Kelebihan USB 2.0 yaitu memiliki kecepatan transfer data yang lebih tinggi sekitar 480 Mbps dibandingkan dengan versi sebelumnya USB 1.1 sekitar 12 Mbps. ${ }^{[2]}$

Standarisasi juga melakukan pembedaan fungsi dari kabel-kabel USB. Ada 4 kabel yang digunakan untuk USB tipe konektor A dan B, konfigurasinya adalah :

Tabel 2.1. Fungsi Kabel USB pada setiap pin konektor.

\begin{tabular}{|c|c|c|}
\hline PIN & WARNA KABEL USB & FUNGSI \\
\hline 1 & MERAH & $\mathrm{V}_{\text {BUS }} 4,4-5,25$ VOLT \\
\hline 2 & PUTIH & D+ \\
\hline 3 & HIJAU & D- \\
\hline 4 & HITAM & GROUND \\
\hline
\end{tabular}

Selain itu terdapat pula konfigurasi kabel USB dengan konektor mini A dan mini B. Konektor mini ini memiliki 5 pin dengan konfigurasi sebagai berikut :

Tabel 2.2. Fungsi Kabel USB pada setiap pin konektor mini A dan B.

\begin{tabular}{|c|c|}
\hline PIN & FUNGSI \\
\hline 1 & V $_{\text {Bus }} 4,4-5,25$ Volt \\
\hline 2 & D+ \\
\hline 3 & D- \\
\hline 4 & ID \\
\hline 5 & GROUND \\
\hline
\end{tabular}


Pin-pin pada konektor mini memiliki fungsi yang sama dengan pin-pin pada konektor standar, kecuali pada pin ke-4 yang disebut dengan "ID". Pin ke-4 ini pada konektor mini-A dihubungkan dengan GROUND. Sedangkan pada mini-B tidak dihubungkan. Spesifikasi USB menyediakan power yang melalui sebuah kabel USB sebesar 5 volt yang terhubung dengan peralatan USB yang mungkin memiliki power tersendiri. Spesifikasi tersebut memberi batas toleransi antara 4,35 volt sampai 5,25 volt. Sedangkan untuk arus yang diperlukan sekitar $100 \mathrm{~mA}$ sampai $500 \mathrm{~mA} .^{[3]}$

\subsection{CHIP BRIDGE PL 250}

PL 2501 adalah sebuah chip tunggal pengendali komunikasi jaringan melalui port USB untuk host controller ke host controller. Chip PL 2501 yang terintegrasi pada kabel USB Network/Bridge memiliki standarisasi Hi-Speed USB 2.0 dengan kecepatan transfer datanya mencapai $480 \mathrm{Mbps}$. Chip tersebut terdiri dari dua interface port USB yang mentransfer data diantara keduanya melalui 2K-byte bulk FIFO untuk transfer bulk bi-directional agar mencapai output bandwidth yang maksimal bagi peralatan USB Hi-Speed. Chip ini memiliki regulator $3.3 \mathrm{~V}$ s/d $5 \mathrm{~V}$ untuk menyediakan power listrik. Chip tersebut juga memiliki dua buah transceivers, backend SIE, dan peralatan logika yang masing-masing satu untuk setiap USB host controller pada komputer. Selain itu chip tersebut memiliki USB core (MCU), dan Buffer Management Unit (BMU). ${ }^{[4]}$

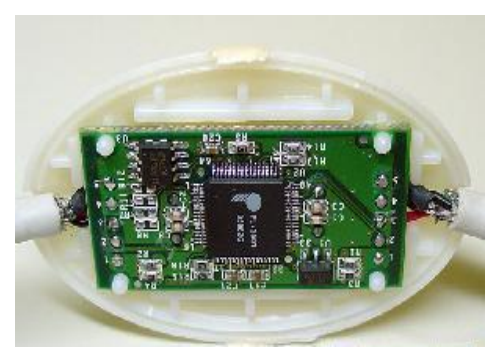

Gambar 2.1 Rangkaian elektronik pada kabel USB Bridge dengan chip PL 2501. 


\subsection{PINOUT CHIP PL 2501}

Chip bridge PL 2501 ini terdapat dua jenis, yaitu PL 2501 LQFP 100 (Low profile Quad Flat Pack dengan 100 pinout) dan PL 2501 LQFP64 (Low profile Quad Flat Pack dengan 64 pinout). Berikut ini adalah gambar dari pinout chip PL $2501:^{[4]}$

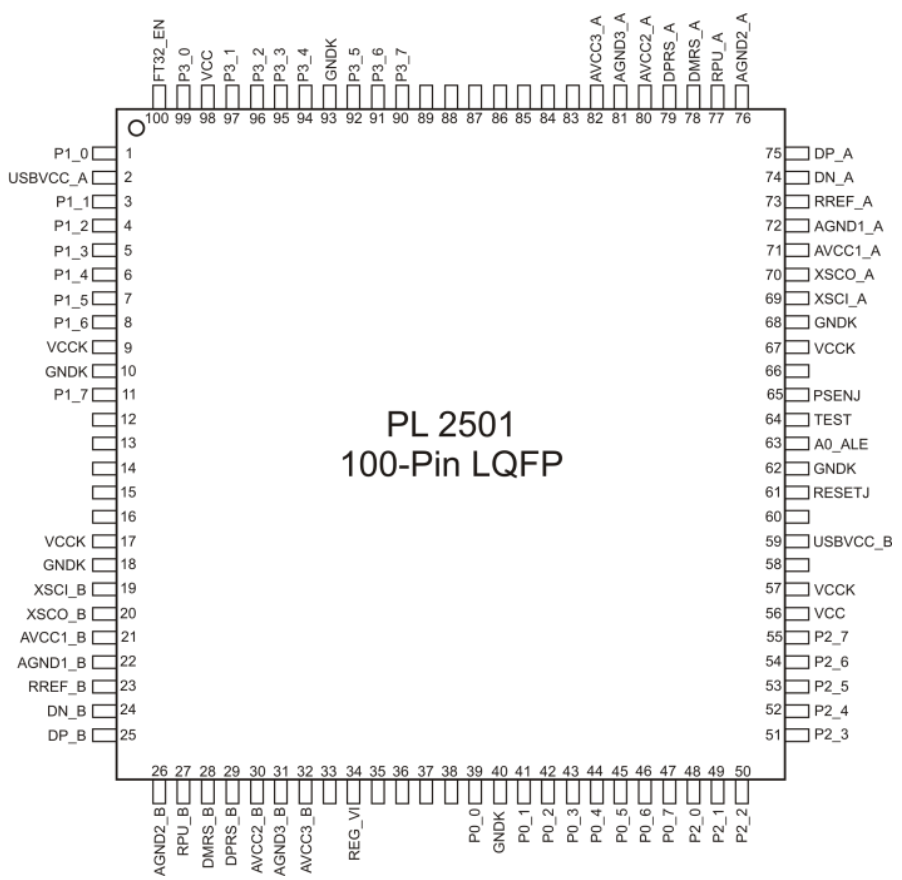

Gambar 2.2 Pinout chip PL 2501 LQFP 100.

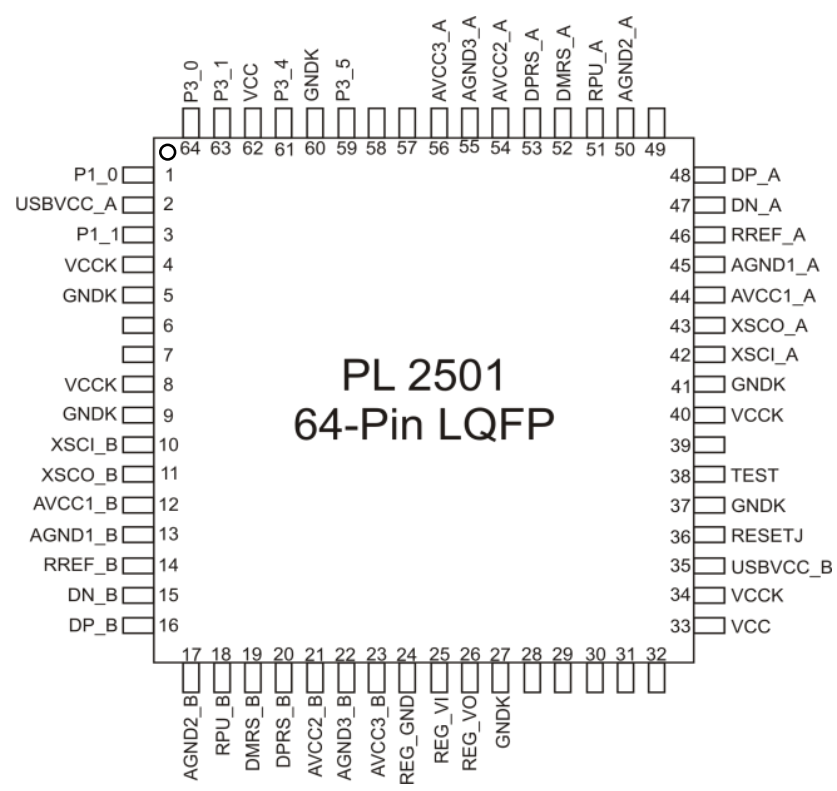

Gambar 2.3 Pinout chip PL 2501 LQFP 64. 
Perbedaan pada kedua chip tersebut adalah pada pin LQFP 100 memiliki program ROM eksternal dan data RAM yang digunakan untuk menyimpan mode driver yang digunakan oleh komputer, sedangkan pada pin LQFP 64 tidak memilikinya. Sehingga pada pin LQFP 64 hanya bekerja pada satu mode untuk driver yang terinstal.

\section{METODE PENELITIAN}

Pada penulisan ilmiah ini penulis menggunakan beberapa metode penelitian sebagai panduan dalam melakukan penelitian dan pengujian koneksi jaringan melalui port USB dengan menggunakan kabel USB Network/Bridge ini, diantaranya sebagai berikut :

a. Studi Pustaka

Dalam metode studi pustaka ini penulis memperoleh data dari buku-buku panduan, buku-buku referensi, artikel pada majalah, serta artikel dalam situs internet tentang jaringan komputer, komunikasi data, pengolahan sinyal digital, sistem USB, port interface USB, pensinyalan pada port USB, dan pentransmisian data oleh port USB, serta katalog chip bridge PL 2501 yang terdapat pada kabel USB Network/Bridge.

b. Penelitian Lapangan

Dalam metode penelitian lapangan ini penulis melakukan observasi secara langsung terhadap masalah yang akan diteliti. Mengamati bentuk fisik dan melakukan uji coba terhadap kabel USB Network/Bridge.

Adapun penelitian yang dilakukan oleh penulis dilaksanakan di Laboratorium Teknik Komputer STMIK Jakarta STI\&K J1. BRI Radio Dalam, Jakarta Selatan sejak Maret - Juli 2007. Jenis data yang diperoleh dari hasil melakukan percobaan dengan sampling data. Dan penganalisaan data yang dilakukan berdasarkan ujicoba atau observasi yang dilakukan secara langsung dengan mengamati bentuk fisik terhadap kabel USB Network/Bridge. 


\section{HASIL dan PEMBAHASAN}

\subsection{BLOK DIAGRAM KONEKSI KABEL USB NETWORK/BRIDGE}

Koneksi jaringan antara dua komputer tanpa ethernet card melalui port USB dengan menggunakan +kabel USB Network/Bridge dapat digambarkan dengan blok diagram sebagai berikut :

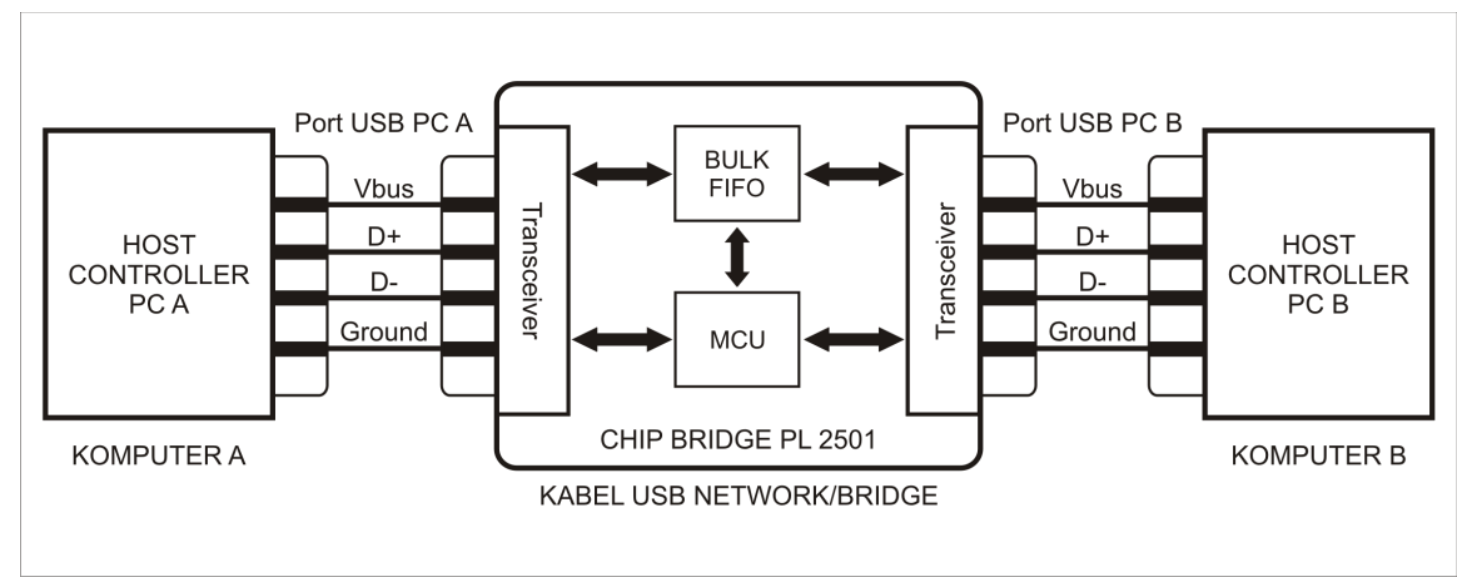

Gambar 4.1. Blok diagram kabel USB Network/Bridge.

Dari gambar blok diagram koneksi kabel USB Network/Bridge diatas dapat dideskripsikan bahwa USB host controller pada kedua komputer saling terhubung melalui kabel USB Network/Bridge dengan chip PL 2501 sebagai peralatan yang mengatur komunikasi data. USB host controller kedua komputer melalui interface port USB terhubung dengan tranceiver chip PL 2501, dan transmisi data melalui bulk FIFO sebagai buffer.

\subsection{BLOK DIAGRAM USB HOST CONTROLLER PADA KOMPUTER}

Terdapat dua jenis interface USB host controller dalam sistem komputer, yaitu UHCI (Universal Host Controller Interface) atau OHCI (Open Host Controller Interface) yang mengatur peralatan USB full/low speed dalam hal ini USB 1.1, dan EHCI (Enhanced Host Controller Interface) yang mengatur peralatan USB hi-speed dalam hal ini USB 2.0 dimana kabel USB Network/Bridge termasuk didalamnya. Berikut ini adalah gambar blok diagram USB host controller pada komputer : 


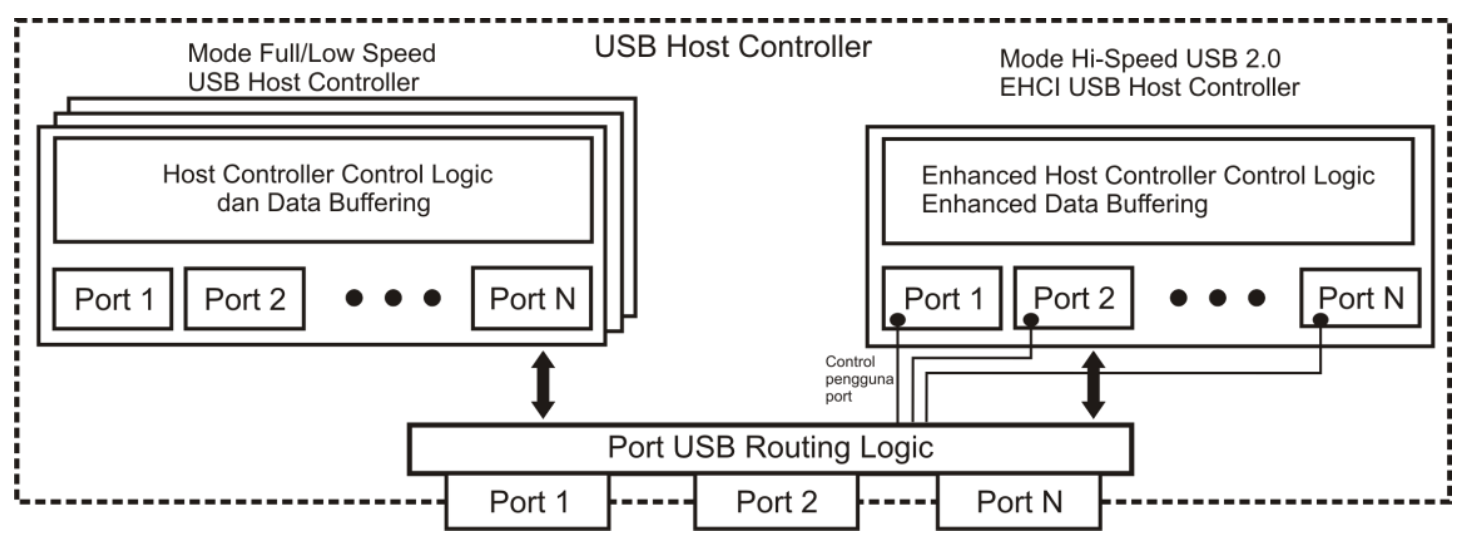

Gambar 4.2. Blok diagram USB Host Controller.

USB Universal/Open host controller digunakan untuk mengatur penggunaan port USB semua peralatan full dan low speed agar terhubung dengan root port USB. Sementara peralatan USB hi-speed selalu diarahkan dan dikendalikan oleh USB Enhanced host controller. Ketika USB enhanced host controller ini telah terkonfigurasi, maka semua root port USB akan dikendalikannya. USB enhanced host controller akan menginisialisasi semua peralatan USB yang terpasang pada port USB, kemudian menginstal driver yang diperlukan agar peralatan tersebut dapat bekerja dengan semestinya.

USB enhanced host controller ini juga memilliki control bit tambahan pada masing-masing port register untuk mengatur logika routing. Sebagai contoh jika terdeteksi peralatan USB yang terpasang pada port USB adalah peralatan full/low speed, maka USB enhanced host controller akan melepas pengendalian port tersebut (termasuk pengendalian kepada peralatan) dan memberikannya kepada USB universal/open host controller. Untuk port USB tersebut terjadi penginisialisasian ulang peralatan USB hingga dapat dikendalikan oleh USB universal/open host controller. Demikian sebaliknya untuk peralatan USB hi-speed, maka USB enhanced host controller akan tetap mengendalikan port tersebut dan menginisialisasi peralatan hingga dikendalikan oleh USB enhanced host controller. 


\subsubsection{ARSITEKTUR INTERFACE USB ENHANCED HOST CONTROLLER}

Arsitektur interface dari USB enhanced host controller didefinisikan ke dalam tiga ruang yaitu :

A. Ruang konfigurasi register PCI, digunakan untuk penghitungan komponen sistem dan manajemen PCI power.

B. Ruang register $\mathrm{I} / \mathrm{O}$ berbasis memori, implementasi untuk parameter dan kemampuan khusus dan ditambah dengan kontrol operasional dan status register. Ruang ini pada umumnya ditunjukkan sebagai ruang $\mathrm{I} / \mathrm{O}$, maka harus diimplementasikan sebagai ruang pemetaan memori I/O.

C. Ruang jadwal (schedule) interface, ruang ini adalah pengalokasian memori khusus untuk penjadwalan periodik dan asynchronous.

\subsubsection{STRUKTUR DATA USB ENHANCED HOST CONTROLLER}

Terdapat dua struktur data yang mengatur dalam transfer data pada USB enhanced host controller, yaitu :

\section{a. Isochronous}

Struktur data ini digunakan untuk transfer data peralatan USB Hi-speed dan Full speed. Struktur data ini hanya digunakan oleh jadwal periodik. Format struktur data isochronous pada periodic frame list link pointer disebut Next Link Pointer. Berikut ini adalah blok diagram deskripsi struktur data isochronous :

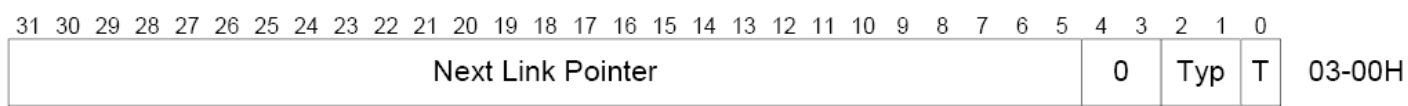

Gambar 4.3 Struktur deskripsi isochronous. 
Berikut ini adalah blok diagram control dan status transaksi isochronous :

\begin{tabular}{|c|c|c|c|c|c|}
\hline Status & Transaction 0 Length & ioc & $P^{*}$ & Transaction 0 Offset $^{\star}$ & $07-04 \mathrm{H}$ \\
\hline Status & Transaction 1 Length & ioc & $P^{*}$ & Transaction 1 Offset* & 0B- $08 \mathrm{H}$ \\
\hline Status & Transaction 2 Length & ioc & $P^{*}$ & Transaction 2 Offset $^{*}$ & $\mathrm{OF}-\mathrm{OCH}$ \\
\hline Status & Transaction 3 Length & ioc & $P^{*}{ }^{*}$ & Transaction 3 Offset $^{*}$ & $13-10 \mathrm{H}$ \\
\hline Status & Transaction 4 Length & ioc & $P^{*}{ }^{*}$ & Transaction 4 Offset $^{\star}$ & $17-14 \mathrm{H}$ \\
\hline Status & Transaction 5 Length & ioc & $P G^{*}$ & Transaction 5 Offset $^{*}$ & $1 \mathrm{~B}-18 \mathrm{H}$ \\
\hline Status & Transaction 6 Length & ioc & $P^{*}{ }^{*}$ & Transaction 6 Offset ${ }^{*}$ & $1 \mathrm{~F}-1 \mathrm{CH}$ \\
\hline Status & Transaction 7 Length & ioc & $P G^{*}$ & Transaction 7 Offset $^{*}$ & $23-20 \mathrm{H}$ \\
\hline
\end{tabular}

Gambar 4.4 Control dan status transaksi isochronous.

\section{Ket : $\square$ Host controller R/W $\square$ Host controller Read Only}

* Field ini akan dimodifikasi oleh USB host controller jika transaksi OUT.

Berikut ini adalah blok diagram dari buffer pointer yang digunakan pada transaksi isochronous oleh host controller :

\begin{tabular}{|c|c|c|c|c|c|c|}
\hline Buffer Pointer (Page 0) & & & $R$ & \multicolumn{2}{|c|}{ Device Address } & $27-24 \mathrm{H}$ \\
\hline Buffer Pointer (Page 1) & $1 / 0$ & \multicolumn{4}{|c|}{ Maximum Packet Size } & $2 \mathrm{~B}-28 \mathrm{H}$ \\
\hline Buffer Pointer (Page 2) & \multicolumn{4}{|c|}{ Reserved } & Mult & $2 \mathrm{~F}-2 \mathrm{CH}$ \\
\hline Buffer Pointer (Page 3) & \multicolumn{5}{|c|}{ Reserved } & $33-30 \mathrm{H}$ \\
\hline Buffer Pointer (Page 4) & \multicolumn{5}{|c|}{ Reserved } & $37-34 \mathrm{H}$ \\
\hline Buffer Pointer (Page 5) & \multicolumn{5}{|c|}{ Reserved } & $3 \mathrm{~B}-38 \mathrm{H}$ \\
\hline Buffer Pointer (Page 6) & \multicolumn{5}{|c|}{ Reserved } & $3 \mathrm{~F}-3 \mathrm{CH}$ \\
\hline
\end{tabular}

Gambar 4.5 Buffer pointer transaksi isochronous.

Ket : $\square$ Host controller Read Only 


\section{b. Queue Head}

Struktur data ini digunakan untuk transfer data peralatan USB Hi-speed, Full speed, dan Low speed. Struktur data ini digunakan untuk mengatur data control, bulk, dan interupt. Struktur queue head terdiri dari karakteristik dan kegunaan endpoint statis serta area kerja dari setiap bus transaksi untuk endpoint yang dieksekusi. Berikut ini adalah blok diagram dari deskripsi queue head :

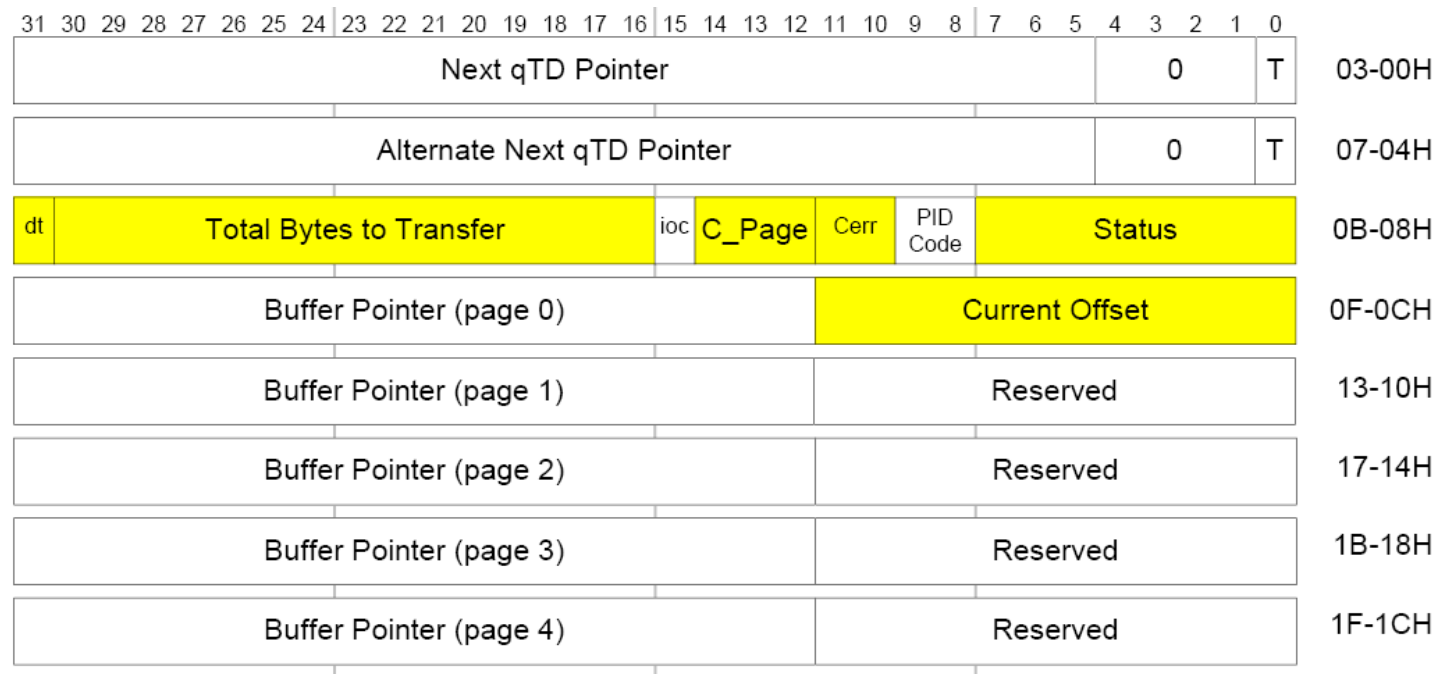

Gambar 4.6 Struktur data Queue Head.

Ket : $\square$ Host controller R/W $\square$ Host controller Read Only

* Field ini akan dimodifikasi oleh USB host controller jika transaksi OUT.

\subsubsection{TRANSFER DATA USB ENHANCED HOST CONTROLLER}

Terdapat dua jenis kategori transfer data yang diatur oleh USB enhanced host controller yaitu periodik dan asynchronous. Transfer data secara periodik meliputi isochronous dan interupsi, sedangkan asynchronous meliputi kontrol dan bulk.

\subsection{BLOK DIAGRAM FUNGSIONAL CHIP BRIDGE PL 2501}

Kabel USB Network/Bridge dengan chip bridge PL 2501 memiliki blok diagram fungsional sebagai berikut : 


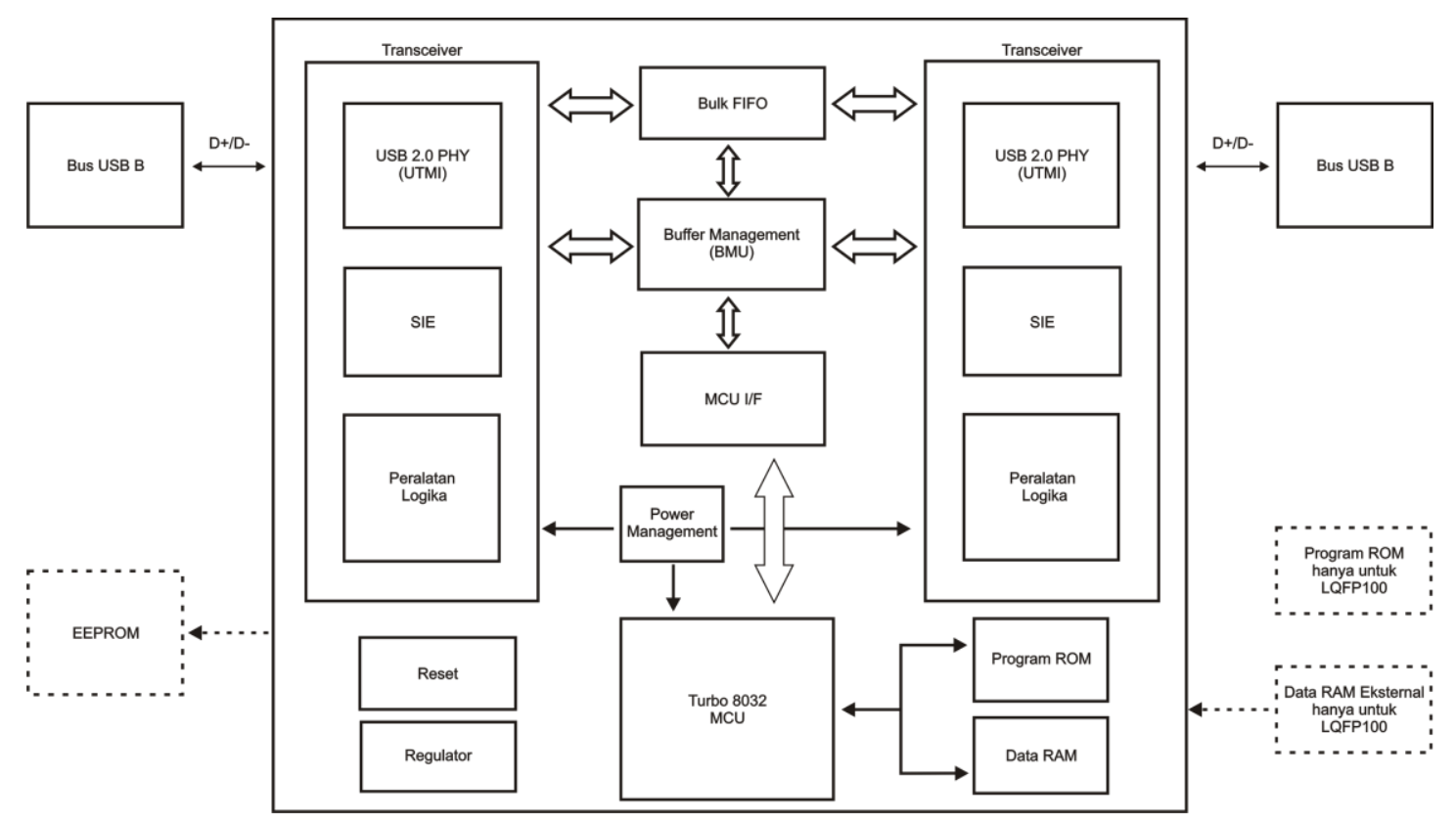

Gambar 4.7 Blok diagram fungsional chip bridge PL 2501.

Dalam blok diagram fungsional tersebut dapat dideskripsikan menjadi dua blok fungsional yaitu : USB Transceiver, dan Core Controller.

\subsubsection{BLOK USB TRANSCEIVER}

Berikut ini adalah gambar blok diagram dari USB Transceiver :

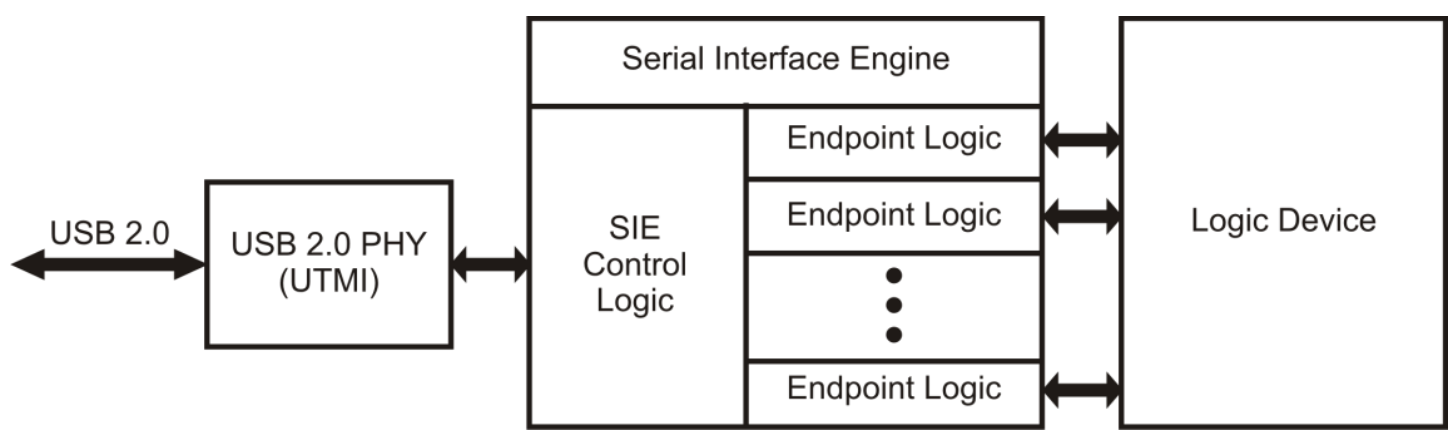

Gambar 4.8 Blok diagram USB Transceiver.

\subsubsection{BLOK CORE CONTROLLER}

Pada blok core controller chip PL 2501 kabel USB Network/Bridge, terdiri dari tiga bagian utama yaitu :

- Bulk FIFO 
Berfungsi sebagai buffer dua arah (bi-directional) pada transfer data yang melalui chip PL 2501.

- BMU (Buffer Management Unit)

Berfungsi menangani dan mengatur aliran data baik data control, interupt, maupun bulk termasuk data control/interupt yang melalui FIFO.

- MCU (Multipoint Control Unit)

Dalam chip PL 2501 ini terdapat dua buah MCU, yaitu MCU I/F dan turbo 8032 MCU. MCU I/F berfungsi dan bertanggungjawab atas pengaksesan memori internal. Selain itu juga berkomunikasi dengan turbo 8032 MCU dalam memproses transaksi data.

\subsection{KONFIGURASI SOFTWARE USB NETWORK/BRIDGE}

Pada prosedur instalasi kabel USB Network/Bridge ini, driver dan software harus diinstal terlebih tanpa memasang kabel USB Network/Bridge pada port USB pada kedua komputer yang akan dihubungkan. Hal ini untuk menghindari kerusakan chip bridge PL 2501 pada kabel USB Network/Bridge karena belum tersedianya driver pada sistem USB di kedua komputer.

\subsection{UJI COBA KABEL USB NETWORK BRIDGE}

\subsubsection{UJI COBA KONEKSI JARINGAN PEER TO PEER}

Dalam uji coba koneksi jaringan ini, penulis membandingkan koneksi peer to peer menggunakan kabel USB Network/Bridge dengan koneksi peer to peer menggunakan kabel UTP Crossover.

Untuk mengkoneksikan jaringan antara dua komputer melalui kabel USB Network/Bridge ini penulis mengatur konfigurasi driver kabel USB Network/Bridge menjadi Hi-Speed USB-USB Network Adapter. Spesifikasi komputer yang penulis gunakan adalah sebagai berikut : 
Tabel 4.1 Spesifikasi komputer yang diuji coba.

\begin{tabular}{|c|c|}
\hline Komputer A (Desktop PC) & Komputer B (Notebook Acer) \\
\hline - $\quad$ Processor P4 2,4 GHz & - $\quad$ Processor Coreduo $1,73 \mathrm{GHz}$ \\
\hline - $\quad$ Memori 512 MB DDR & - $\quad$ Memori 512 MB DDR2 \\
\hline - Ethernet Card 10/100 Mbps & - $\quad$ Ethernet Card 10/100 Mbps \\
\hline - $\quad$ OS Windows XP Profesional SP2 & - $\quad$ OS Windows XP Profesional SP2 \\
\hline - Computer Name : GANG & - Computer Name : TIQUL \\
\hline
\end{tabular}

\subsubsection{KONFIGURASI INTERNET PROTOCOL (TCP/IP)}

\section{A. Hi-Speed USB-USB Network Adapter.}

Berikut ini adalah tabel konfigurasi TCP/IP pada kedua komputer :

Tabel 4.2 Konfigurasi TCP/IP Hi-Speed USB-USB Network Adapter.

\begin{tabular}{|c|c|c|c|}
\hline \multicolumn{2}{|c|}{ Komputer A } & \multicolumn{2}{|c|}{ Komputer B } \\
\hline IP Address & : 192.168.0.5 & IP Address & : 192.168.0.2 \\
\hline Subnet Mask & $: 255.255 .255 .0$ & Subnet Mask & : 255.255.255.0 \\
\hline Default Gateway & : 一.-.... & Default Gateway & -.....- \\
\hline
\end{tabular}

Setelah melakukan konfigurasi tersebut penulis melihat status koneksi jaringan yang menggunakan Hi-Speed USB-USB Network Adapter yaitu Local Area Connection 3.

\section{B. Ethernet Card Network Adapter.}

Tabel 4.5. Konfigurasi TCP/IP Ethernet Card Network Adapter.

\begin{tabular}{|lc|lc|}
\hline \multicolumn{2}{|c|}{ Komputer A } & \multicolumn{2}{c|}{ Komputer B } \\
\hline IP Address & $: 192.168 .0 .1$ & IP Address & $: 192.168 .0 .123$ \\
Subnet Mask & $: 255.255 .255 .0$ & Subnet Mask & $: 255.255 .255 .0$ \\
Default Gateway & $:-.-.+.-$ & Default Gateway & $:-., .-.-$ \\
\hline
\end{tabular}

Setelah melakukan konfigurasi tersebut penulis melihat status koneksi jaringan yang menggunakan Ethernet Card Network Adapter yaitu Local Area Connection. Berikut ini adalah gambar status koneksi jaringan menggunakan Ethernet Card : 


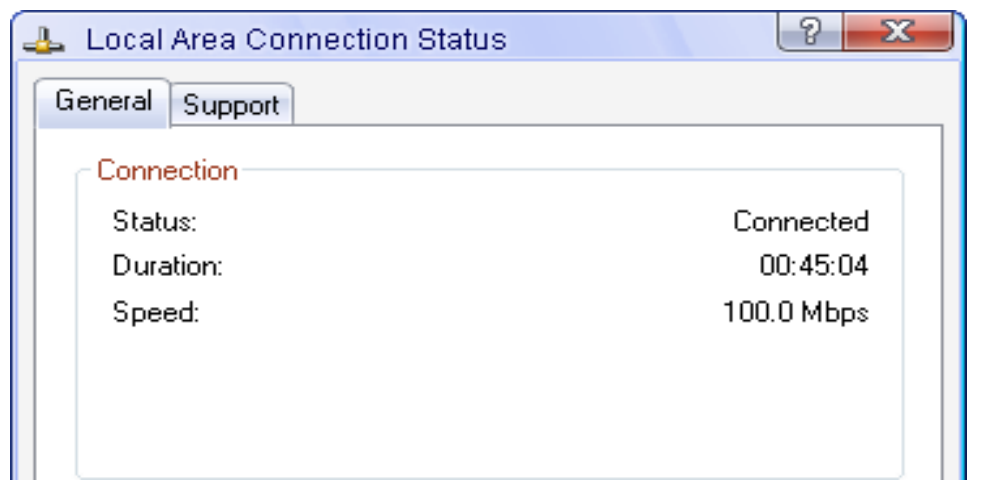

Gambar 4.9 Status koneksi jaringan menggunakan Ethernet Card.

Dalam gambar tersebut, kecepatan koneksi sebesar $100 \mathrm{Mbps}$, hal ini membuktikan bahwa koneksi menggunakan kabel USB Network/Bridge memiliki kecepatan transfer rate empat hingga lima kali lebih cepat daripada menggunakan Ethernet Card.

Hal ini dapat pula di uji dengan perintah ping pada command prompt dengan memberikan buffer maksimum, sebagaimana pada gambar berikut ini :
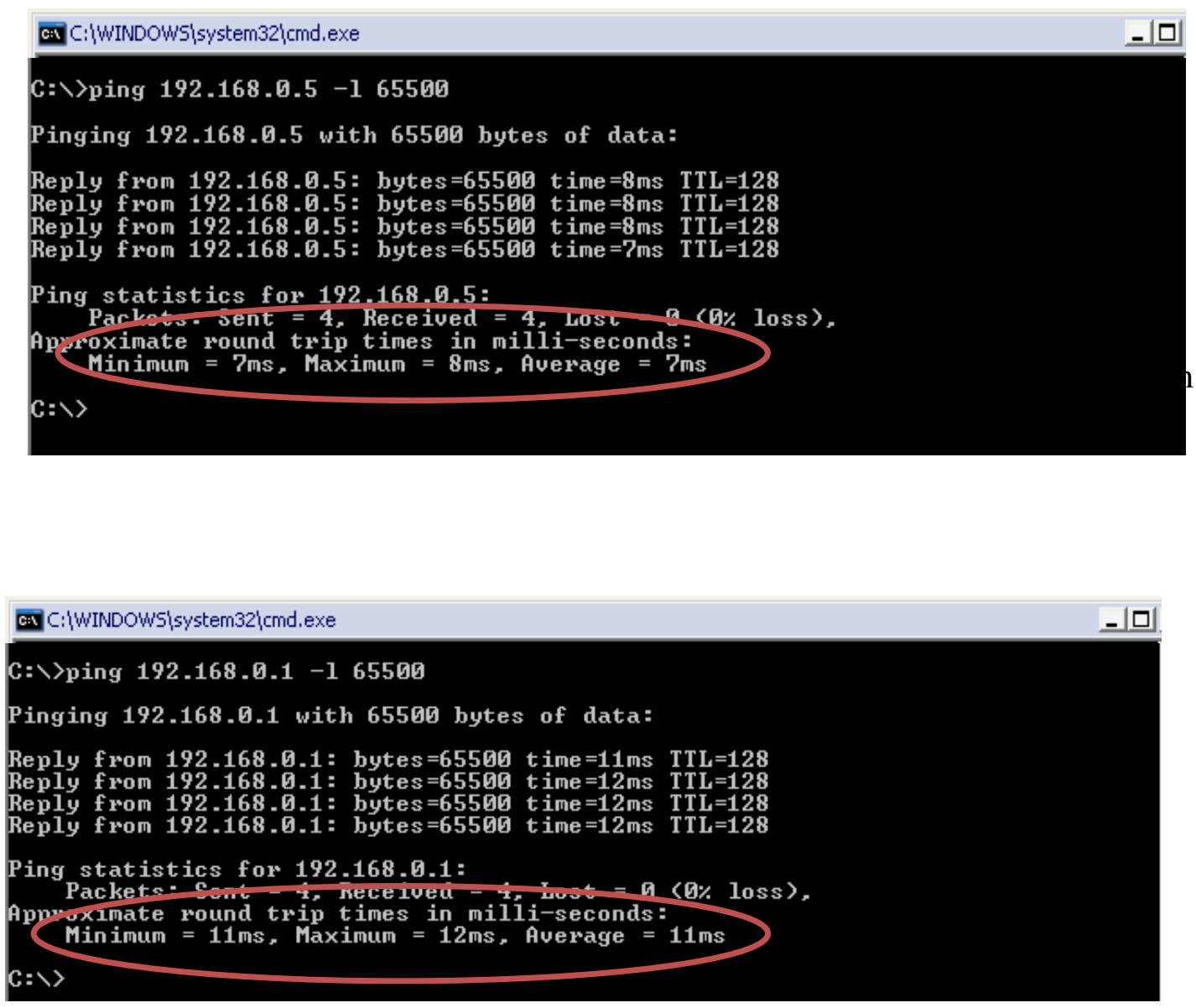
Dari kedua gambar tersebut, Approximate round trip times yang diperlukan pada koneksi menggunakan kabel USB Network/Bridge dalam mili-second adalah :

Minimum $=7 \mathrm{~ms} \quad$ Maksimum $=8 \mathrm{~ms} \quad$ Rata-rata $=7 \mathrm{~ms}$.

Sedangkan pada koneksi menggunakan Ethernet Card dalam mili-second adalah :

Minimum $=11 \mathrm{~ms} \quad$ Maksimum $=12 \mathrm{~ms} \quad$ Rata-rata $=11 \mathrm{~ms}$.

Analisa dari percobaan tersebut bahwa penggunaan kabel USB Network/Bridge dalam koneksi jaringan peer to peer antara dua komputer dapat meningkatkan kinerja dan efisiensi dalam transmisi data bila dibandingkan dengan Ethernet Card.

\subsubsection{UJI COBA TRANSFER DATA}

Dalam uji coba transfer data ini, penulis membandingkan transfer data dari komputer A ke komputer B menggunakan kabel USB Network/Bridge dengan transfer data menggunakan kabel UTP Crossover dalam koneksi jaringan peer to peer antara dua komputer.

Dalam percobaan transfer data ini, file yang digunakan adalah bervariasi baik file data, file suara, maupun file video. Berikut adalah tabel percobaan transfer data yang penulis lakukan :

Tabel 4.6. Perbandingan waktu transfer data.

\begin{tabular}{|c|c|c|c|}
\hline No & $\begin{array}{c}\text { UkuranFile } \\
(\mathbf{M b})\end{array}$ & $\begin{array}{c}\text { Waktu Transfer Kabel USB } \\
\text { Network/Bridge (mnt:det) }\end{array}$ & $\begin{array}{c}\text { Waktu Transfer } \\
\text { Ethernet Card (mnt:det) }\end{array}$ \\
\hline 1 & 174 & $00: 18$ & $00: 23$ \\
\hline 2 & 630 & $02: 01$ & $03: 29$ \\
\hline 3 & 1618 & $04: 25$ & $04: 28$ \\
\hline 4 & 2007 & $04: 28$ & $05: 02$ \\
\hline 5 & 2294 & $04: 28$ & $05: 26$ \\
\hline
\end{tabular}

Analisa dari data pada tabel tersebut bahwa terdapat perbedaan waktu dalam transfer data menggunakan kabel USB Network/Bridge dengan menggunakan Ethernet Card berikut ini : 
- Pada data pertama terdapat perbedaan waktu 5 detik untuk ukuran file $174 \mathrm{Mb}$, dengan menggunakan kabel USB Network/Bridge memerlukan waktu 18 detik sedangkan menggunakan Ethernet Card memerlukan waktu 23 detik.

- Pada data kedua terdapat perbedaan waktu 1 menit 5 detik untuk ukuran file 630 $\mathrm{Mb}$, dengan menggunakan kabel USB Network/Bridge memerlukan waktu 2 menit 1 detik sedangkan menggunakan Ethernet Card memerlukan waktu 3 menit 29 detik.

- Pada data ketiga terdapat perbedaan waktu 3 detik untuk ukuran file $1618 \mathrm{Mb}$, dengan menggunakan kabel USB Network/Bridge memerlukan waktu 4 menit 25 detik sedangkan menggunakan Ethernet Card memerlukan waktu 4 menit 28 detik.

- Pada data keempat terdapat perbedaan waktu 34 detik untuk ukuran file $2007 \mathrm{Mb}$, dengan menggunakan kabel USB Network/Bridge memerlukan waktu 4 menit 28 detik sedangkan menggunakan Ethernet Card memerlukan waktu 5 menit 02 detik.

- Pada data kelima terdapat perbedaan waktu 58 detik untuk ukuran file $2294 \mathrm{Mb}$, dengan menggunakan kabel USB Network/Bridge memerlukan waktu 4 menit 28 detik sedangkan menggunakan Ethernet Card memerlukan waktu 5 menit 26 detik.

Dari analisa tersebut bahwa transfer data antara dua komputer menggunakan kabel USB Network/Bridge memerlukan waktu yang lebih baik antara 3 detik hingga 1 menit 5 detik dibandingkan dengan menggunakan Ethernet Card.

Secara teori seharusnya kecepatan transfer data menggunakan kabel USB Network/Bridge lima kali lebih cepat bila dibandingkan dengan menggunakan ethernet card, namun perbedaan yang tidak mencapai perbandingan 1:5 membuktikan banyak faktor yang mempengarhi kecepatan transfer data seperti gangguan dalam transmisi data yang dapat berupa atenuasi yaitu berkurangnya kekuatan sinyal karena adanya hambatan pada media kabel USB Network. 


\section{KESIMPULAN \& SARAN}

Dalam koneksi jaringan antara dua komputer dengan menggunakan kabel USB Network/Bridge melalui port USB memiliki sifat dan fungsi yang sama dengan koneksi menggunakan Ethernet Card melalui kabel UTP Crossover, yaitu adanya alamat IP, kemampuan berbagi file dan printer, dan kemampuan untuk berbagi koneksi internet.

Kelebihan yang dimiliki koneksi dengan menggunakan kabel USB Network/Bridge adalah dalam kecepatan transfer datanya yaitu mencapai $480 \mathrm{Mbps}$ (USB 2.0), lima kali lebih cepat bila dibandingkan dengan menggunakan Ethernet Card yang standar kecepatan transfer datanya mencapai 100 Mbps. Namun perbedaan yang tidak mencapai perbandingan 1:5 pada uji coba transfer data membuktikan bahwa banyak faktor yang mempengarhi kecepatan transfer data seperti gangguan dalam transmisi data yang dapat berupa atenuasi yaitu berkurangnya kekuatan sinyal karena adanya hambatan pada media kabel USB Network.

Untuk perkembangan yang lebih baik dalam membangun LAN dengan menggunakan kabel USB Network/Bridge ini adalah dengan mengurangi gangguan transmisi data sehingga kecepatan transfer data dapat optimal.

Selain itu dalam membangun LAN dapat pula mengkombinasikan antara kabel USB Network/Bridge dengan kabel UTP. Ataupun dalam perkembangannya, USB hub sudah terintegrasi dengan chip bridge sehingga tidak memerlukan lagi kabel USB dengan chip bridge.

\section{DAFTAR PUSTAKA}

[1]. Anonim, "PL-2501 Hi-Speed USB Host-to-Host Bridge/Network Controller", http://www.prolific.com/product/ds_pl2501_v1.3.htm, Juni 2007.

[2]. Howard, John S. et all, "Enhanced Host Controller Specification for Universal Serial Bus", http://www.intel.com/technology/usb/ehcispec.htm, Maret 2002.

[3]. Mcgowan, Steve, "USB 2.0 Transceiver Macrocell Interfacce Specification", http://www.intel.com/technology/usb/2_0_Xcvr_Macrocell.htm, Maret 2001. 
[4]. Peacock, Craig. "USB in-a-Nutsheel”, http://www.beyondlogic.org/usb.htm, Desember 2000.

[5]. Stalling, William. “Komunikasi Data dan Komputer : Jaringan Komputer”, edisi pertama, Salemba Teknika, Jakarta, 2002.

[6]. Thomas, Robert. M. "Pengantar Local Area Network", PT. Elex Media Komputindo, Jakarta, 1996. 